\title{
Every museum has a God, or God is in every museum?
}

Chaque musée a un Dieu, ou Dieu est dans chaque musée?

\section{Bruno Brulon Soares}

\section{(2) OpenEdition \\ Journals}

Electronic version

URL: http://journals.openedition.org/iss/1358

ISSN: 2306-4161

Publisher

ICOM - International Council of Museums

\section{Printed version}

Date of publication: 12 October 2019

Number of pages: $57-72$

ISBN: 978-92-9012-467-2

ISSN: 2309-1290

\section{Electronic reference}

Bruno Brulon Soares, «Every museum has a God, or God is in every museum? », ICOFOM Study Series [Online], 47(1-2) | 2019, Online since 12 October 2019, connection on 24 October 2019. URL : http:// journals.openedition.org/iss/1358 


\title{
Every museum has a God, or God is in every museum?
}

\section{Bruno Brulon Soares}

\author{
Universidade Federal do Estado do Rio de \\ Janeiro - Rio de Janeiro, Brazil
}

ABSTRACT

The provocative hypothesis according to which museums are religious public spaces aims to threaten the unwavering secular status of these institutions in the West. In order to interrogate museum agency as secular, we must first ask a question: what is the religion behind every museum? The article proposes the decolonisation of the museum performance, understood as a magical act that in certain conditions produces religious effects. For this purpose, two French exhibitions presented by the Musée du quai Branly were analysed: the museum inaugural exhibition at the Pavillon des Session (2000), at the Louvre, and the short-term exhibition "Mãori. Leurs trésors ont une âme", presented in the museum's current building from 4 October 2011 to 22 January 2012, both displaying collections of non-European religious objects.

Key words: museology, museum, religion, beliefs, cultural difference. 


\section{R'́s U Ḿ}

\section{Chaque musée a un Dieu, ou Dieu est dans chaque musée ?}

L'hypothèse provocative selon laquelle les musées sont des espaces publics religieux vise à menacer le statut laïc indéfectible de ces institutions en Occident. Pour interroger l'agence muséal en tant que laïque, nous devons tout d'abord poser une question : quelle est la religion derrière chaque musée ? L'article propose la décolonisation de la performance muséale, comprise comme un acte magique produisant des effets religieux dans certaines conditions. A cette fin, deux expositions françaises présentées par le musée du quai Branly ont été analysées : l'exposition inaugurale du musée au Pavillon des Session (2000), au Louvre, et l'exposition temporaire « Mãori. Leurs trésors ont une âme ", présentée dans le bâtiment actuel du musée du 4 octobre 2011 au 22 janvier 2012, tous deux avec des collections d'objets religieux non européens.

Mots clés : muséologie, musée, religion, croyances, différence culturelle.

$$
\text { 丈 }
$$

\section{Introduction}

The light is translucid and dramatic. The wide empty space gives a certain mystery to the objects of devotion elevated before the small crowd of curious and believers. A woman kneels in prayer showing some sort of possession. There is no indication that the museum gallery isn't a religious place. Art is on the altar.

The gallery of the Louvre entitled Pavillon des Sessions, which was opened to the public in the year 2000 as the first showcase of the Musée du quai Branly ${ }^{1}$, is a vast space of I.4OO square meters that exhibits a small, selective collection of "primitive art" from the four non-European continents of the world. As noted by the anthropologist Maurice Godelier, the great majority of the objects displayed were somehow related to power: the power of African sovereigns, of gods, of spirits, etc. (Godelier, 2007, p. 27). In a way, beyond their beauty in the European eyes, they represent unbreakable bounds between humans and an invisible world.

I. Inaugurated in 2006, now the museum is called Musée du quai Branly - Jacques Chirac. 
Despite the predominance of aesthetics over religion, and the discourse of art invested in the exhibition, since it was inaugurated in a so called "universal" museum, it has been a stage for the spontaneous manifestation of several acts of faith. Over the years, some of the religious objects displayed as art have witnessed the deposition of offerings before them, or the prayer of individual visitors in the museum space (Delannoy, 2002, p. 23 in Price, 2007, p. 79). Recently, one of the guards stated that religious manifestations are not allowed in the Pavillon. According to him, the manifestation of any faith shouldn't indeed be permitted and in cases like the one described above the person in the prayer is asked to stop "disturbing" other visitors. "It is a public space after all," " he says.

After intentionally requalifying the ethnographic value of the objects exhibited $^{2}$, the European curators behind the Louvre exhibition resorted to the language of art in order to restrict the audience experiences to a secular single perception of these works. According to Germain Viatte, a Canadian curator trained in France who was responsible for the museological sector behind the exhibition, the collection of the future quai Branly was supposed to enter "into another magic". In his view, the conception of the exhibition was in itself "a sort of magic", being the magical act complete with "the transmission to the audience" (Viatte, 2006). This museum "magic", in this sense, has in its centre the authentic object that is exposed "in its density, its weight, its skin". Thanks to the object there is magic in the museum. Thanks to visitors there is faith in its power of authenticity. But it is the curator who is the author of the magical act.

In this article we propose to decolonise the museum performance, here understood as a magical act that in certain conditions may produce religious effects. The religious aspect of the museum can be seen, in this analysis, as a provocative hypothesis that threatens the unwavering secular status of this institution in the West. Created as a temple for the dissemination of civilised values, for the legitimation of a certain power and for nourishing the faith in the sovereign and in the state, the modern museum presents as many paradoxes as the modern church. Museums are based on one single culture, while pretending to be universal; they sustain their discourse with "science" but still need social magic to produce public faith; they are secular institutions with undeniable religious effects...

Museums are sacred in the sense they presuppose a certain set of beliefs from their audience. Belief in the truth - of science, art or religion. Belief in the object, in its authenticity. Belief in a "God" that hides the intentional work

\footnotetext{
I. Anonymous interview, Musée du Louvre, February 2018.

2. The collection that originated the Musée du quai Branly comes from the ethnographic collections of the Musée de l'Homme and the Musée National des Arts d'Afrique et d'Océanie, both traditional ethnographic institutions in France.
} 
of curators. Belief in the act of magic and in the unspoken religion of secular priests.

\section{Is God in every museum? Consecrating secularism as religion}

To interrogate the museum performance as secular, we must first ask ourselves: what religion is behind every museum? As secular institutions, museums advocate for the laicity of public space. Exhibitions should respect such a principle as a universal law for the representation of God and all religions in the museum.

However, when exhibiting religious objects without any mention of the previous use given to them before entering a European collection, isn't the museum making a religious decision of its own? In other words, isn't secularism a form of religion consecrated by museums?

After the Enlightenment and the French Revolution, which established in the $I 8^{\text {th }}$ century the universal public institution, the idea of the museum as a "sacred temple" was defined as the consequence of a new mentality in Europe, in the beginning of what was called modernity. The movement for the "exploitation of knowledge" at all costs, that followed the invention of the printing press, the great discoveries in the New World, and the "scientific revolution" led to the development of museums as central means for the dissemination of knowledge in the process of colonisation. At this point in Western ${ }^{\mathrm{r}}$ history, there was not a single dominant ideology, and the contact with the colonies instated a sense of insecurity for European culture and knowledge. As a result, new forms of imperialism and the so-called modern instruments for knowledge production and dissemination were invented. A renewed interest in "the savages" (Clastres,I978, p. 209) was built upon the belief that different societies were somehow culturally connected, a widespread dogma for modern sciences and those who studied them.

Museums, then and now, helped to sustain such a dogma, performing the classification of difference within the new-born "civilisation". For this purpose, social and cultural hierarchies had to be sustained with "scientific proof" of the fact that some people were inferior to others - in their cultures, social organisation and systems of beliefs. A clear comparison was made with the European cultural model, known as civilised and thought to be a universal standard. Such a standard has been sustained and argued as the "rule" to measure all museums in the contemporary world, as it was explicit in the "Declaration of the Importance and Value of Universal Museums", a document produced in 2002 by 19 museums from North America and Europe that were identified

\footnotetext{
I. The West, in this paper, is regarded as a European invention in contrast with the East, as a symbolic construction that designates the belief in social hierarchies based on the power relations that sustained colonialism in the world. See Said, Edward W. (1978). Orientalism. London, UK: Routledge and Kegan Paul.
} 
as the Bizot group. These museums' directors debated, among other things, the presence of non-European objects in their collections and the political implications behind repatriation. The Declaration, published on behalf of "the international museum community", stated that "museums serve not just the citizens of one nation but the people of every nation" (ICOM, 2004, p. 4).

Constructed as devices of the truth regarding a certain cultural viewpoint believed to be superior to others (the one of universal museums and their directors), museums instated the cult of a form of authenticity (Mairesse, 20I4), based on the assumption of the true object in contrast with the false. This museum performance, over the years, has authenticated particular values that were behind the idea of civilisation. Such a performance, or the re-enactment of colonial power, was not only at the base of certain beliefs intrinsically bound to European modern tradition, but it has as its ultimate mission to produce the belief in this very tradition, as universal and monotheistic.

The museum liturgy, as defined by François Mairesse (2014), is a result of a certain ideology that was spread in the different corners of the world and which was founded, in its most general and dominant assumption, on the idea of the universality of museology. Since museum practice was shaped in the world through different international schools and training programs, museology has evolved with clear centres of resonance for the theory ${ }^{\mathrm{I}}$ and normative directions for professionals all around. A supposedly universal ethics code was established by ICOM in the last decades of the $2 \mathrm{O}^{\text {th }}$ century ${ }^{2}$ aiming to guide the museum profession and the professional conduct around the globe. While considering museums as non-religious institutions, and preserving their sacred secularism, the ICOM code of ethics considers that sacred materials must be acquired and exhibited respectfully to the religion of the groups from whom they came from:

Human remains and materials of sacred significance must be displayed in a manner consistent with professional standards and, where known, taking into account the interests and beliefs of members of the community, ethnic or religious groups from whom the objects originated. (ICOM, [2006] 2017, p. 25).

\section{9}

Due to this window opened to the sacred in their collections, museums, as secular as they wish to be, are susceptible to "religious sensibilities" (FavretSaada, 20I7). Over the years, after the end of colonisation, several museums in the West have been accused by religious organisations of hurting someone's beliefs by exhibiting "blasphemous objects". When exhibitions are being closed for showing "sensible" religious materials or for contradicting a certain moral

I. See Brulon Soares \& Leshchenko (2018).

2. The first version of ICOM Code of Ethics for Museums dates from I986. 
code, the manifestation of religious reactions towards the museum is more and more frequent, in a time when democratic institutions are facing unprecedented crisis. It is, therefore, more relevant than ever to explore the relation between cultural difference, politics and religion in this secular temple.

\section{Objects of faith and faith as a social object}

Aiming to discuss the manifestation of faith in museums, our research considered two French exhibitions presented by the Musée du quai Branly, in Paris: the museum inaugural exhibition at the Pavillon des Session (2000), at the Louvre, still open today, and the short-term exhibition entitled "Mãori. Leurs trésors ont une âme", presented in the museum's current building from 4 October 2 II to 22 January 20I2, both displaying collections of non-European religious objects. The analysis of the museum performance in these two exhibitions that marked the museum history in the past two decades allow us to identify different expressions of faith in museum's devotees.

While in classical anthropology "faith" or "beliefs" - used in the plural - were commonly admitted as an object to be collected by ethnologists in the fieldwork, it has recently achieved new, more complex levels of interpretation in the human sciences. In the past, the beliefs of certain societies were studied as elements of experience offered for ethnologist's observation and whose designation of the term did not demand any previous investigation (Bonte \& Izard, I99I, p. I84).

This perspective led "belief" to be understood in its social utility, in a way that ethnologists would deliberately choose not to distinguish between beliefs and collective representations. More frequently, the term "belief" was used to refer to the known objects of conviction, such as gods, spirits, ancestors, genius, masks, magic, etc. Whichever was the ethnologist's point of view, the study of beliefs ignored the psychological aspect as the only element that allows one to specify a belief in comparison to other conscience states. Such an aspect resides in the mental attitude expressing the level of certainty with which someone adopts an idea, interpreting something as truthful or real (Bonte \& Izard, I99I, p. I84-185).

This objectification of belief is founded on the postulate of the universality of human aptitude for belief (Needham, 1972 in Bonte \& Izard, 199I). According to this postulate, there would be no society without a "system of beliefs". The Western conception of beliefs based on the observation of non-Western societies have been applied notably to religion, defined by Durkheim as "a unified set of beliefs and practices relative to sacred things" (I995 [I9I2], p. 34). While this sociologist considers that "there are religious phenomena that do not fall under the jurisdiction of any particular religion" (Durkheim, 1995 [I9I2], p. 34), it was in the studies developed by Marcel Mauss (200I [I972])

I. In English, "Mãori. Their treasures have a soul". 
that a distinguished idea of "religion" as the result of social practice, would be defined in relation to "magic" as isolated acts. From this point, a moral value is attributed to religion, as an organised, public, set of beliefs, defining as magical all the rites that fall outside of the organised forms of cults.

These early works, in a way, helped classical anthropology to assume the fact that ethnologists must be disbelievers, who have no faith of their own, and yet they believe in the belief of others (Pouillon, I979 apud Bonte \& Izard, I991, p.I85). To study someone else's beliefs, then, was "to be interdicted, firstly, of recognising any truth in them" (Favret-Saada, 2007 [1977]). Therefore, all matters of "believes" were included in the domain of "apparently irrational believes" (Sperber, 1982) or, they were simply defined as "magic" or "witchcraft".

As demonstrated by Jeanne Favret-Saada, the works of folklorists have placed "witchcraft" as the belief of others, presumed to be inferior to their own disbelief. These "scientists" would only talk about witchcraft provided they could set themselves apart from it, and describe it as "a particular childish, preposterous and ridiculous set of beliefs" (2007, p. I6-I7). The arrogance of the traditional folklorist in this matter defines the observer as being in an external position, which will allow her or him to hear "nothing but wanderings", collecting, as a result, objective statements and fantastic anecdotes.

Based on the assumption that beliefs are supposed to be discredited or disbelieved in order to be studied, some museums are, still today, performing their own magic and ignoring the effects of the magic of others. Possessed of the "European spirit", museologists and museum professionals refuse to recognise their own faith in the museum performance. Reaffirming their disbelief, they maintain a cultural distinction between beliefs and the necessary distance from varied forms of "witchcraft", or "artificial" cults - such as the ones defined by the terms "macumba" and "voodoo" sometimes used to depreciate African cults.

Different museologies presuppose different expressions of faith that allow visitors to engage in the museum performance as we envision it. Let us, here, suppose that there is such thing as museum magic, instead of struggling to deny our faith. In this case, we might accept it as "an act of communication" (Favret-Saada, 2007) that creates a mediation between what is known and the unknown. I believe that then, and only then, we can connect with a particular form of human experience, a sacred experience, that is the museum experience.

\section{The belief of the disbelievers}

To experience the museum as a museum believer implies assuming, firstly, that affirmed disbelievers have a belief. When the quai Branly project was being conceived in the r99os, by the collector Jacques Kerchache and with the

\footnotetext{
I. The author describes witchcraft as "magic operating without the help of a material prop", in contrast with the notion of sorcery, or instrumental magic, as distinguished by Evans-Pritchard (1937) in his early ethnography of the Zande of South Sudan (Favret-Saada, 2007, p. 34).
} 
political support of the future French president, Jacques Chirac, a new form of "adoration" of the arts produced by colonised people was invented. Kerchache defended that the art of indigenous peoples from Africa, Oceania, Asia and the Americas needed to be "liberated." This was the main reason behind the exhibition at the Louvre. As a result, in the presentation and re-enactment of the objects of "primitive art" in the new exhibition, this commissaire d'exposition creates a new dogma for the collections displayed, proposing one - and one only - possible interpretation for them, according to his very clear artistic intentions.

Kerchache's manifesto "for the arts premiers to be born free and equal", was published in Libération, in I990, and signed by ${ }_{4} 8$ international personalities, most from Europe - among which the ethnologists Georges Balandier and Michel Leiris ${ }^{2}$. According to all of them, non-European art needed a temple in Europe. With so many renowned supporters, the "magician" Kerchache could establish the new museum.

Some of the most evident contradictions involving the so-called primitive arts - later renamed, in France, "arts premiers" - are visible in the Louvre/quai Branly exhibition. The acquisition and musealisation criteria of these objects mostly sculptures - show the impossibility of isolating the particular aesthetic envisioned by Kerchache from the anthropological connotation. For instance, several of the objects on display, only a few steps away from the Mona Lisa, are religious objects used in rituals outside the European context.

For Gaetano Ciarcia, the language of art applied to these collections meant a "reification of these objects' appearance, which produces an effect of obligation in the eye" (Ciarcia, 200I, p. 342). Paradoxically, while we are obliged to look at a ritual mask as art, the language of art obliges the "freedom of the eye" that was invented in the West. This way, we can supposedly look at the same mask and see either a sculpture, or a mask in an imagined ritual context, or even a surrealist inspiration. This apparent contradictory relation to the object of art, in the eye that is obliged to be free, is what sustains, nowadays, a belief in the place of primitive art in metropolitan museums as a "fair" cultural representation.

The development of several studies in anthropology of art has helped to sustain a belief in the "freedom" of culturally and religiously charged objects in art museums. Alfred Gell (I995) in his attempts to differentiate the study of art from the study of religions noted that the latter is based on what Peter Berger has called "methodological atheism" (Berger, I967, p. Io7 in Gell, I995, p. 4I). For the scientist of religions there are no genuine religious truths and it is not of her/his concern to discover them - neither it is to believe in them.

\footnotetext{
I. "Commissaire d'exposition" is the French term that denotes the person in charge of intellectually conceiving an exhibition, similar to the English term "curator" less used in France. 2. «Manifeste pour que les chefs d'œuvre du monde entier naissent libres et égaux».
} 
According to Gell, the consequences of the possibility that there are religious truths lie outside the frame of reference of the sociology of religion (I995, p.4I). From this point, the author exposes a distinguished faith that is the one of the sociologist of art or the disbeliever, who believes in the "religion of art" or in the religion of the museum (also known as "museology").

In this secular religion, whose dogmas and commandments have been formulated and set in stone by the modern museum, the principle of the True and the Good resides in the aesthetically valued object (Gell, I995, p. 4I-42) that is also reverenced by devotees as authentic. The paradox here lies in the fact that, at the core of Western culture and knowledge, it is through material objects that one might find a path toward transcendence. In this religion that is our own, the religion of the museum, we have sacralised art and culture according to a moral code that is, in itself, culturally bounded. The Western museum is our religion; and our faith lies in the fact that we have no faith, because the museum is universally secular. God forbid that we sin against this sacred institution.

The debate on museums and museum exhibitions as a realm of faith leads us to a fundamental question: what is the belief of the disbelievers? As temples of a past imagined to be believed, or "churches" where civilised people venerate their ancestors, are museums places of a secular faith? And, as previous experiences have shown, if secularism does not necessarily exclude the expression of faith and the value of beliefs, shouldn't we be asking ourselves, when visiting an exhibition, what is the religion of its curator?

A museum exhibition is invariably the result of the choices of certain individuals - sometimes based on the mission and social commitment of an institution and sometimes very much based on their individual values or taste. In fact, what a curator decides to display or to hide in a certain museum discourse is very much related to who this professional is and to what she or he believes. In this sense, there is no exhibition devoid of a belief, because even the belief of the disbeliever is a form of believing.

\section{The museum supremacy: two exhibitions, one single religion}

Over the years since the quai Branly opened its permanent exhibitions to the public in its exotic new building, the gallery of primitive art in the Louvre remained as a souvenir and a manifesto of Kerchache's initial intentions. However, despite the exhibition design and the obvious aesthetic criteria behind the selection of objects to be displayed, this representation of "primitive art" in a classical museum still evokes prayers and raise questions of faith for the audience. By declaring that only one interpretation of the objects is allowed in the museum space, are curators presupposing the supremacy of curatorship over the visitor's experience? When curators assume that a certain aesthetic will dictate how objects in an exhibition will be perceived, is the visitor's own religion or cultural background solemnly disregarded? 
During the second half of the I990s, when the anthropologist Maurice Godelier occupied the scientific direction of the quai Branly, several discussions were conducted to established what would be the scope of the exhibition at the Pavillon des Sessions, as well as the ones in the future museum building, which was opened only in 2006. In these initial debates, the committee formed to give a direction to the new museum was divided between "museological" and "scientific" responsibilities (Price, 2007, p. 49). Envisaging a post-colonial museum where art and ethnology could symmetrically coexist in the same space, Godelier wished to assure that visitors could "pass from the joy of seeing to the joy of knowing" thanks to the information available on the societies behind the works on display (Godelier, 2000 in Price, 2007, p. 50). Later, the ethnographic project was suppressed by Kerchache and the supremacy of the aesthetic experience preconised by this curator led most of the ethnologists on the staff to abandon the project at a certain point. As Price recalls it:

The dominant feeling within the committees was that aesthetic contemplation was best achieved through quiet communion with the object [my emphasis], and that the distraction of ethnographic information should be kept at a distance. (Price, 2007, p. 51).

In a critical approach to the universal sense of "beauty", Gell (1995) declares his belief in a necessary break with aesthetics, so that scientists can achieve a true non-religious interpretation of art. However, what he proposes as a solution to the anthropology of art is, in fact, the replacement of one form of religion - the religion of art - for another system of beliefs that is behind all the other forms of secular religions and to which he is also a devotee: the religion of science. Scientists believe in the supremacy of reason and in its ultimate goal, which is the transcendence toward knowledge and enlightenment. Also configured in European modernity, having encyclopaedic museums and Western universities as their temples, modern sciences are not less a religion than art.

Thus, in his notion of the "technology of enchantment" as an object more likely to be deciphered by skeptical scientists, Gell ignores his own set of beliefs, disregarding such a thing as the religion of science. When defining art as a technical system "oriented towards the production of the social consequences which ensue from the production of these objects" (I995, p. 44), he presupposes a universal power of art objects originated from the technical processes they objectively embody. Such a technology of enchantment depends on the assumption that every person will experience the same effects when in contact with the same incantation. Furthermore, the author fails to notice that the value of objects in a museum as art is less connected to their technical fabrication than it is to a concrete local history and their successive appropriation in the different regimes of value, including by experts and collectors (Bazin, 2008, 
p. 507). In other words, in his attempt to set a new scientific method for the interpretation of art objects, Gell demonstrates that the supremacy of the museum is based on the supremacy of the material object in its collections.

Others have contested the idea of aesthetics as "a cross-cultural category" (see Ingold, 1996). According to these authors, the supremacy of aesthetics over the social has allowed museums to define the cult of the art object as the only legitimate museum experience. In its most accepted conception, this cult comprises the "sacred triad" (Overing, I996, p. 2II) of the individual artist, the art object and the individual contemplator of the object. The problem with this conception lies in the fact that museum visitors generally come from different places, have different beliefs and belong to particular religions that are not the same as the one of the curators - a fact that is particularly evident in the two exhibitions considered for the present analysis.

The communion between different systems of beliefs is a challenge for museums that intend to implement exhibitions based on shared curatorship. As several experiences of indigenous museologies in central museums have shown, these shared practices should involve the definition of syncretic zones in the museum scenario, where it is possible to respect and value different faiths.

In 20II, the quai Branly presented a collaborative exhibition with a religious and political theme, in contradiction with the museum's initial project for the arts prémiers. The exhibition "Mãori. Leurs trésors ont une âme" reflected the museum's attempt to decolonise its own practices and to interrogate the supremacy of aesthetics to the detriment of indigenous experiences. The itinerant exhibition, conceived by the Mãori people at the Museum of New Zealand Te Papa Tongarewa to be presented at the quai Branly, was the product of a binational collaboration between the two national museums. It had as a counterpart the return of several Mãori heads that belonged to the collection of the French museum to the Te Papa, as a recognition of the sacred value of these objects.

The exhibition had the purpose of "giving word to the Maori" as stated in French media, celebrating the "self-representation" by the Mãori in the Parisian museum. It was conceived with a double interest: on the one hand, to innovate, presenting a new approach to those objects in the French context, on the other, it kept the quai Branly aesthetics in the design for the museum space.

In fact, when visiting the exhibition, it is the aesthetic approach that predominates to the non-indigenous eye - accustomed to the museum use of colours and light to create an artistic performance with ethnographic materials. A visitor, such as myself, a non-initiated to the Mãori culture, but familiar to the "quai Branly effect", could only relate to those objects aesthetically, and their sacred and political value was secondary to my own experience in the French museum. Visitors were invited to touch some of the objects on display,

I. "Donner la parole aux Maori" (Musée du quai Branly; New Zealand Museum Te Papa, 20II). 
supposedly to "feel their souls", according to Mãori beliefs, in clear contrast with the museum's long-term exhibition where other Mãori objects were presented as art.

In practice, the exhibition was the result of long negotiations between the two museums and two different perspectives over indigenous culture and "art". While telling the story of Mãori pride and identity, it was formatted to suit the agenda of the arts premiers, more committed to express a certain aesthetics rather than to represent indigenous history and heritage. The winding space of the museum unveils the value of Mãori heritage to the Eurocentric eye throughout a visually seductive circuit. The different elements of Mãori culture are used as decorative elements, sometimes with no explanation for their symbolic value beyond aesthetics. Beauty helps to hide some cultural meanings, and the religion of art is once again sovereign.

In the Mãori perspective over these objects, the musealisation does not implicate in their necessary desacralisation. However, in the end, the mana evoked by the Mãori, as the vital force that travels through all things and persons, could be reinterpreted at the quai Branly as the power of art in the museum. Somehow, the museum performance transforms religious objects into art. The visitors are once again led to be enchanted by Kerchache's magic.

\section{Every museum has a God?}

What differentiates the short-term exhibition "Mãori. Leurs trésors ont une âme" from the initial project of the quai Branly, displayed at the Pavillon des Sessions, is an attempt to "regenerate" the sacred value of certain objects (Derlon \& Jeudy-Ballini, 2001/2002, p. 208-209) resorting to indigenous interpretation, which was incorporated in the museum's own narrative while still obeying its founding dogmas. It is clear, in this case, how indigenous claims for decolonisation of the museum have provoked the recognition of other faiths, or other museologies, by contradicting the Eurocentric approach to religious objects.

The decolonisation of indigenous cultures by museums has implied - in cases such as the Mãori exhibition - the decolonisation of museum practice and the re-evaluation of museology's main paradigms and principles. So that they can acknowledge indigenous believes and non-European faiths, museums must recognise a belief of their own. Curators and anthropologists who decided in a recent past to open the doors of their institutions to beliefs other than their own were obliged to see, first, their system of beliefs as one among many others, recognising difference as a central museum object. To be affected (Favret-Saada, 2007) by other people's faiths, and to keep the doors open for different experiences of the sacred, is a contemporary challenge for the post-colonial museum.

However, defenders of this supposed secular institution have argued that the efforts of museums in a post-colonial situation to reconcile multiple faiths can put them at risk of reaching a state of discursive infertility, jeopardizing 
museums' social role, or the faith society invests in them (see, for instance, Derlon \& Jeudy-Ballini, 200I/2002). According to this perspective, the regeneration of the sacred value of an object is a betrayal of the museum's fundamental faith. One can argue that museums assume the role of sanctuaries, in direct contradiction to their own secular "religion", when restoring to collections their sacred value while keeping them musealised. So, are museums that decide to respect different religious sensibilities actually hurting their own faith in laicity?

By proposing a sacred interpretation of the museum object, Jean Bazin (2008) notes that despite the efforts to de-sacralise, the object remains a sign of the religious act it no longer performs. The ability to transit between the museum universe and the ritual universe simultaneously - as the objects in several indigenous museums in the world have proven to be possible - put into question the very rigid theories on the transition into art or the transition into musealia (museum object).

In both the exhibitions here referenced, we may observe the sacred life of the musealised object - the object having made the transition into a distinguished level of symbolic existence through museum magic. To devotees of aesthetics, the ritual objects displayed as art in the Louvre were perceived as non-religious. In this case, objects transcend their own ritual role in the religion where they were first used to incorporate another magic in the museum religion. For the Mãori objects presented at the quai Branly short-term exhibition, mana was the force that provoked a certain magical effect on visitors - be they Mãori or European. In that particular performance, the mana invested in the objects could be interpreted as the new syncretic magic invented by the quai Branly.

By admitting museum objects as magical objects and musealisation as a magical act, we are closer to breaking away from the supremacy of the museum. In Bazin's terms, objects in a museum are "available", at the disposal of someone to whom they serve (2008, p. 523). They are supports for the experimental possibilities that may arise from the social encounter between the beliefs behind the museum project and the ones of visitors. Exhibitions are, then, built upon micro-devotions and this is where museums differ from other orthodox temples. Different than the church, the museum does not attract people for one single hegemonic type of cult. Because their religion presupposes the liberation of the believer, as well as of the actual space where faith is manifested, the museum religion must be open to diversity.

It is in pursuit of fulfilling the role of an institution for cultural and religious diversity that museums of one single faith have been opening their doors to alternative forms of the sacred that do not presuppose laicity. Indigenous beliefs that in the past have given sense to religious objects collected by anthropologists in the field, are now frequently explained by the very people who gave sense to them. Exhibitions commonly re-enact religious altars and some museums are known as ritual spaces for different ethnic groups. In these temples of diversity, there is no faith that is wrong or untrue. 
If an object of faith enters into "another magic" once initiated to the museum religion, in the new syncretic museum, this "museum magic" means being in touch with different magics at the same time. In this sense, it is possible to evolve from the supremacy of the museum devoted to one sovereign God, towards museums that admit believing in different gods, or even venerating several gods at once.

\section{Conclusions: are we devotees of a supremacist museology?}

Objects in a museum constitute the "theatre of a second birth" (Grognet, 2005, p. 2). They are, as the actor in a performance, simultaneously in two places at once; they are being re-enacted in the museum stage, but they are, at the same time, sacred for those who bend in adoration to them. They are "caught" in a double magic: the one of the museum, and the one of the people who believe in another faith. Because museums are altars of this transition from one sacred into another, the museum object is a liminal object, in the constant state of becoming something it is not. A change was made; and yet the object remains the same. It is adored because of the ties that bind it to the new museum reality, but it can still evoke, to certain devotees, a different magic, never lost, always potent, as a presence the museum cannot suppress.

If museums are temples for a magic in which we, as museum professionals or researchers, are also "caught", maybe we should be asking to which God are we praying, before judging someone else's faith. In the perspective here explored, assuming that we are believers in the museum religion is the same as admitting that we participate in the cult of European gods. The museum liturgy as we know it and as we learned it was founded in European tradition and is still based on Eurocentric dogmas. To recognise how such dogmas direct our own faith and practice is the first step towards the deconstruction of our temple.

Museology in itself was organised in terms of different beliefs regarding what the museum could be and how its magic could be explained. A set of somehow dogmatic ideas was defined as the Theory of Museology, adopted in some works as commandments or unquestionable truths. Museum liturgy is followed and practiced as it is taught in theory in the different contexts of the world, as if only one single Museology was possible.

But like anthropologists of religion who must have a non-religious point of view to be impartial towards their subject of analysis, must we, museologists, also leave our faith aside when studying our temple or deciphering its truths? On the contrary, in order to understand the visitors' point of view when immersed in museum magic, we must allow ourselves to be affected by the very magical act we help to perform. As magicians, we are strong believers in our own act, which also means that we need to be constantly reminded of the fact that other religions are welcome in the museum temple. 
What we have ultimately intended to unveil in the present article is the idea that believing in one single Museology used to shape and sustain museum practice is, in fact, to corroborate with the very dogmas we - as museologists or scientists of the museum - should be trying to analyse and question. To deconstruct the temple should be the goal of a critical museological reflection.

As temples of sacred secularism, museums are also a battlefield for different moral interpretations of reality, manifested through religion and critical of other "ideologies" different than their own. A conscious museology can build possible bridges between religions, instead of raising walls to exclude "pagan" gods using the excuse of taste or aesthetics to justify political positions. As recent examples have shown, the museum is a useful device for the interpretation of reality, but it can also be misinterpreted once perceived as a secular institution for one specific audience that prays for a God that stands alone.

\section{References}

Bazin, J. (2008). Des clous dans la Joconde. L'anthropologie autrement. Toulouse Anacharsis.

Bonte, P., \& Izard, M. (Dir.). (1991). Dictionnaire de l'ethnologie et de l'anthropologie. Paris : Quadrige/PUF.

Brulon Soares, B., \& Leshchenko, A. (2018). Museology in Colonial Contexts: A Call for Decolonisation of Museum Theory. ICOFOM Study Series, 46, 6I-79.

Ciarcia, G. (200I). Croire aux arts premiers. L'Homme, I58-I59, 339-354.

Clastres, H. (1978). Sauvages et civilisés au XVIII ${ }^{e}$ siècle. In F. Châtelet (Dir.), Histoire des ideologies (pp. 209-228). Paris: Hachette.

Derlon, B., \& Jeudy-Ballini, M. (200I/2002). Le culte muséal de l'objet sacré. Gradhiva, 30/3I, 202-2II.

Durkheim, É. (I995 [19г2]). The elementary forms of religious life. New York, N.Y.: The Free Press.

Favret-Saada, J. (2007 [1977]). Les mots, la mort, les sorts. Paris: Gallimard.

Favret-Saada, J. (2017). Les sensibilités religieuses blessées. Christianismes, blasphèmes et cinéma. 1965-1988. Paris : Fayard.

Gell, A. (1995). The technology of enchantment and the enchantment of technology. In: COOTE, Jeremy \& SHELTON, Anthony (ed.). Anthropology, Art and Aesthetics. Oxford: Clarendon Press, pp.40-63. 
Godelier, M. (2007). Les métamorphoses de la qualification. In B. Latour (Dir.), Le dialogue des cultures. Actes des rencontres inaugurales du musée du quai Branly (2I juin 2006) (pp. 2I-68). Babel, 82I.

Grognet, F. (2005). Objets de musée, n'avez vous donc qu'une vie? Gradhiva [En ligne], 2, mis en ligne le ro décembre 2008. Retrieved from: http:// gradhiva.revues.org/473, consulted in January, 2012.

ICOM - International Council of Museums. (2017 [2006]). Code of Ethics for Museums. Retrieved from: http://archives.icom.museum/ethics.html, consulted in I4 February, 2018.

ICOM - International Council of Museums. (2004). Declaration of the Importance and Value of Universal Museums. ICOM News, n. I, p.4.

Ingold, T. (1996). (Ed.). Key debates in anthropology. London \& New York: Routledges.

Mairesse, F. (2014). Le culte des musées. Bruxelles: Académie royale de Belgique.

Mauss, M. (200I [1972]). A general theory of magic. London \& New York: Routledge.

Musée du quai Branly; New Zealand Museum Te Papa. (20II). Mãori. Leurs trésors ont une âme. Exhibition brochure.

Overing, J. (1996). Aesthetics is a cross-cultural category. Against the motion (I). In T. Ingold (Ed.), Key debates in anthropology (pp. 260-265; 270-293). London \& New York: Routledges.

Price, S. (2007). Paris primitive. Jacques Chirac's Museum on the Quai Branly. Chicago \& London: The University of Chicago Press.

Said, E. W. (1978). Orientalism. London, UK: Routledge and Kegan Paul.

Sculptures: Afrique Asie Oceanie Amériques. (2000) Paris: Réunion des musées nationaux.

Sperber, D. (1982). Les savoir des anthropologues. Paris : Hermann.

Viatte, G. (2006). In A. Viatte (Prod.), L’Autre Musée. Musée du Quai Branly. IDVD (52 min.), color. 